\title{
La Inquisición en tiempos de Fray Luis de León. El proceso contra el bachiller Juan Escribano, regente de griego en el Colegio Trilingüe de la Universidad de Salamanca (1575-1576) ${ }^{1}$
}

\author{
Francisco Javier Rubio Muñoz ${ }^{2}$
}

Recibido: 3 de noviembre de 2016 / Aceptado: 29 de noviembre de 2016

Resumen. El proceso inquisitorial contra el bachiller Juan Escribano, regente de griego en el Colegio Trilingüe de la Universidad de Salamanca, debe ser contextualizado dentro de la atmósfera intolerante que envolvió a la segunda mitad del siglo XVI, en donde la Inquisición persiguió a todo aquel que mostrase comportamientos o pensamientos heterodoxos. Las cuestiones doctrinales se mezclaban con las personales, de modo que la delación ante el Santo Oficio fue un hecho que escondía, en muchas ocasiones, enemistades y venganzas que poco tenían que ver con el cuestionamiento de la ortodoxia católica. El caso de Escribano fue uno más a los que añadir a la larga lista de intelectuales procesados por la Inquisición, del mismo modo que había ocurrido con Fray Luis de León, Martínez de Cantalapiedra y Gaspar de Grajal, a cuyo círculo habría pertenecido el helenista.

Palabras clave: Juan Escribano; Inquisición; Universidad de Salamanca; Colegio Trilingüe; siglo XVI.

[en] The Inquisition in the time of Fray Luis de León. The Trial against Bachelor Juan Escribano, Professor of Greek at the Trilingual College of the University of Salamanca (1575-1576)

\footnotetext{
Abstract. Inquisition trial against bachelor Juan Escribano, regent of Greek at the Trilingual College of the University of Salamanca, should be contextualized within the intolerant atmosphere that enveloped the second half of the sixteenth century, where the Inquisition persecuted anyone who might show heterodox thoughts or behaviors. Doctrinal and personal matters appear linked, so the accusation before the Inquisition hid, many times, hostility and vendettas that had little to do with questioning the doctrine. The case of Escribano was one of a long list of intellectuals tried by the Inquisition, just as it has happened to Fray Luis de León, Martínez de Cantalapiedra and Gaspar de Grajal, whose circle the hellenist would have belonged.

Keywords: Juan Escribano; Inquisition; University of Salamanca; Trilingual College; 16th century.

Sumario. 1. Introducción. 2. El Colegio Trilingüe y Juan Escribano. 3. El proceso inquisitorial contra Juan Escribano: su prisión en Valladolid. 4. Sobre las causas del proceso inquisitorial. 4.1 Enemigos en el Trilingüe. 4.2. Enemigos en el claustro universitario. 4.3. Intentos de clausura del Trilingüe. 5. Conclusión.

$1 \quad$ La presente investigación se enmarca en el Proyecto de Investigación "Las Universidades Hispánicas (siglos XV-XIX): España, Portugal, Italia y México. Historia, saberes e imagen” (HAR 2012-30663), financiado por el Ministerio de Economía y Competitividad del Gobierno de España.

2 Universidad de Salamanca kopolo@usal.es
} 
Cómo citar: Rubio Muñoz, F.J. (2017) La Inquisición en tiempos de Fray Luis de León. El proceso contra el bachiller Juan Escribano, regente de griego en el Colegio Trilingüe de la Universidad de Salamanca (1575-1576), en Cuadernos de Historia Moderna 42.1, 107-127.

Yo he llegado aquí después de esta mi infeliz jornada que caminé más por ajena culpa que por mía.

Juan Escribano. ${ }^{3}$

\section{Introducción}

El control férreo del Tribunal de la Inquisición sobre la doctrina, la moral y el pensamiento de la sociedad tuvo uno de sus momentos álgidos tras el Concilio de Trento. Así, la segunda mitad del siglo XVI fue un tiempo de intolerancia; baste mencionar la publicación del Índice de libros prohibidos por el inquisidor Fernando de Valdés, el proceso del arzobispo Carranza o la prohibición de Felipe II de salir fuera de la Monarquía a estudiar en otras Universidades para ejemplificar la intransigencia de ese momento ${ }^{4}$. La Inquisición, como adalid de la ortodoxia teológica y doctrinal católica, y como elemento de control del Estado, velaba por la eliminación de cualquier signo de disidencia intelectual o en las costumbres.

Este complejo escenario, empero, coincidió con la etapa de mayor esplendor de la Universidad de Salamanca, la cual, como institución encargada de la formación del personal de la Monarquía Hispánica, no se escapó de la estricta vigilancia del Santo Oficio; más bien todo lo contrario. Algunos de sus miembros fueron perseguidos por mantener ideas diferentes a las de la doctrina oficial de la Iglesia, bien de forma verbal o a través de sus escritos. Este contexto es el que se debe tener en cuenta en la polémica entre escolásticos y hebraístas, disputa aparentemente teológica en torno al valor de la Vulgata que se saldó con el proceso y encarcelamiento de Fray Luis de León, Martínez de Cantalapiedra y Gaspar de Grajal ${ }^{5}$.

Petición de rehabilitación del bachiller Juan Escribano, catedrático de griego de la Universidad de Salamanca, dirigida al claustro de la Universidad, el 27 de octubre de 1576. Archivo Histórico de la Universidad de Salamanca (AUSA), Claustros, leg. 45, fol. 166 v. Véase Beltrán de Heredia, V. (ed.): Cartulario de la Universidad de Salamanca, Salamanca, Ediciones Universidad de Salamanca, 1972, vol. 4, p. 309.

4 Rodríguez-San Pedro, L. E.: "La Universidad hispana del Renacimiento", en Pérez, J. y otros (eds.): El siglo de frai Luis de León. Salamanca y el Renacimiento. Catálogo de la exposición organizada por el IV centenario de la muerte de Fray Luis de León, Salamanca, Ministerio de Cultura-Ediciones Universidad de SalamancaJunta de Castilla y León, 1991, p. 51; Tomás y VAliente, F.: "El proceso penal”, Historia 16, Extra I «La Inquisición» (1993), p. 19.

5 La notoriedad de estas figuras, sobre todo la de Fray Luis de León, ha centrado el debate historiográfico en torno a las relaciones de la Universidad de Salamanca y la Inquisición. A modo de referencia, véase DE LA PINTA Llorente, M. A. (ed.): Procesos inquisitoriales contra hebraistas de Salamanca, Gaspar de Grajal, Martínez de Cantalapiedra y Fray Luis de León, Madrid, Monasterio de El Escorial, 1935. De LA Pinta Llorente, M. A. (ed.): Proceso criminal contra el hebraista salmantino Martín Martinez de Cantalapiedra, Madrid, CSIC, 1956. Alcalá, A. (ed.): El proceso inquisitorial de Fray Luis de León, Salamanca, Junta de Castilla y León, 1991. Barrientos, J.: Fray Luis de León y la Universidad de Salamanca, Madrid, Ediciones Escurialenses, 1996. Concretamente, sobre Fray Luis de León, el proceso íntegro se publicó en SALvé, M. y SAINZ DE Baranda, P.: Colección de documentos inéditos para la Historia de España [en línea], Madrid, Imprenta de la viuda de Calero, 1847, vols. 10 y 11, https://archive.org/details/coleccindedocu10madruoft, [consulta: $12 \mathrm{de}$ enero de 2016]. Así mismo, el profesor San José Lera creó un portal web dedicado a su figura y su obra, con numerosa bibliografía. Véase www.cervantesvirtual.com/portales/fray_luis_de_leon/?conten=presentacion. Una recopilación bibliográfica en Lazcano, R.: Fray Luis de León. Bib̆liografiā, Madrid, Editorial Revista 
La animadversión de enemigos dentro y fuera del ambiente académico se disfrazaba de acusaciones por cuestiones doctrinales o lecturas prohibidas, en un momento en el que, al calor del Humanismo, las discusiones teológicas eran bastante frecuentes en el contexto académico. De forma coetánea a la prisión de los hebraístas, las persecuciones del Santo Oficio tuvieron como objetivo a otros profesores de la Universidad de Salamanca ${ }^{6}$. Éste fue el caso del protagonista de esta historia, el bachiller Juan Escribano, catedrático de griego en el Colegio Trilingüe de dicha Universidad, el cual, a pesar de ser elogiado como persona y por su labor docente, no pudo evitar su proceso inquisitorial y su encarcelamiento entre 1575 y 1576.

Juan Escribano fue un importante helenista, aunque poco conocido, cuya vida se desarrolló en el marco universitario salmantino de la segunda mitad del quinientos. Había nacido en torno a 1533 en Salamanca, según lo que declaró en varias ocasiones delante de los visitadores del Colegio Trilingüe ${ }^{7}$. De sus años precedentes a su labor como profesor poco se sabe, si bien son más que probables sus orígenes modestos, como solía ocurrir entre los catedráticos dedicados a la enseñanza de lenguas. Además, los exiguos salarios de estas lecturas eran la causa de que las penurias económicas estuvieran a la orden del día entre este sector del profesorado, y, en el caso de Juan Escribano, fueron realmente pocos los bienes -a excepción de una espectacular biblioteca de más de 1600 volúmenes- que dejó al morir ${ }^{8}$. Su labor académica se centró únicamente en la regencia de una cátedra menor de griego desde 1559 hasta su muerte en $1590^{\circ}$. Por otro lado, se le conocen algunas composiciones literarias, como la participación en las justas poéticas convocadas por la Universidad de Salamanca en 1571 con motivo de la victoria de Lepanto, o unos versos incluidos en la obra De musica libri septem del maestro Francisco de Salinas, con quien mantuvo una estrecha relación. ${ }^{10}$

\section{Agustiniana, 1994.}

6 Así ocurriría después con el maestro Francisco Sánchez de las Brozas, El Brocense, cuyo proceso, al igual que el del agustino, ha sido bien estudiado. Véase Tovar, A. y De la Pinta Llorente, M. A. (eds.): Procesos inquisitoriales contra Francisco Sánchez de las Brozas, Madrid, CSIC, 1941.

7 AUSA, Visitas Trilingüe, leg. 2134, fol. 43 r.

8 Los aspectos biográficos del bachiller Juan Escribano y sus vínculos con algunos miembros del Colegio Trilingüe se han estudiado con mayor profundidad en RuBio MuÑoz, F.J.: "La vida en el Colegio Trilingüe a través del bachiller Juan Escribano, catedrático de griego de la Universidad de Salamanca en la segunda mitad del siglo XVI". CIAN. Revista de Historia de las Universidades, 20 [en prensa], así como en la tesis doctoral defendida por el autor en la Universidad de Salamanca en junio de 2017 y titulada "El profesorado en las Universidades Hispánicas del Siglo de Oro. El caso de Salamanca y sus proyecciones”, la cual recibió la calificación de Sobresaliente "cum laude" con mención de Doctor Internacional.

9 Así se menciona en el claustro de diputados del 25 de mayo de ese 1559 en donde "proveyeron de la regencia de griego del Colegio Trilingüe desta Universidad al bachiller Juan Escribano, con partido de 20.000 maravedís en cada un año e de comer en el dicho Colegio segund y como se daba al bachiller Diego Hernández". AUSA, Claustros, leg. 28, fol. 52. Algunos aspectos académicos relacionados con la enseñanza del griego son señalados por López Rueda; con él coincidimos en señalar los numerosos elogios dedicados a Escribano. Véase LóPEz RuedA, Helenistas españoles del siglo XVI, Madrid, CSIC, 1973, pp. 98 y ss.

10 En el asunto de las justas por la victoria de Lepanto no consiguió premio, aunque sus versos macarrónicos son considerados de una gran calidad. En cualquier caso, su condición humilde y la entera dedicación a la enseñanza del griego posiblemente no le permitieron desarrollar una actividad intelectual más amplia. Véase LóPEZ DE Toro, J.: Los poetas de Lepanto, Madrid, Instituto Histórico de Marina, 1950, p. 181 (poema en pp. 199-201); Domínguez Leal, J. M.: "Compendio de la poesía macarrónica en España y de su influencia en la literatura española”, Calamvs renascens. Revista de humanismo y tradición clásica, 2 (2001), p. 204. Con respecto a la dedicatoria de Juan Escribano al maestro Salinas, véase SALINAS, F.: De musica libri septem in quibus eius doctrinae veritas tam quae ad hamoniam, quam quae ad rhythmum pertinet, iuxta sensus ac rationis iudicium ostenditur \& demonstratur, Salamanca, Mathias Gast, 1577, p. XXIII. Para una edición crítica reciente, véase Salinas, F.: De musica libri septem (edición al cuidado de Amaya García Pérez y Bernardo García-Bernalt Alonso), Salamanca, Ediciones Universidad de Salamanca, 2013. 
En las páginas que siguen abordaremos los problemas que Juan Escribano tuvo con la Inquisición. Hasta la fecha poco se sabía del proceso contra el regente de griego, entre otras cosas, porque el documento se halla perdido ${ }^{11}$. A pesar de ello, existen otras fuentes para reconstruir las posibles causas del mismo, como son las cartas enviadas desde el Santo Oficio de Valladolid al Tribunal de la Suprema Inquisición de Madrid, conservadas en el Archivo Histórico Nacional, así como los Libros de Visitas del Trilingüe y varios Libros de Claustros del Archivo Histórico de la Universidad de Salamanca ${ }^{12}$. La primera de las fuentes describe algunos momentos por los que pasó Juan Escribano en las cárceles de la Inquisición vallisoletana. Aunque la posterior libertad del helenista parece que puso fin a su persecución, la información que aportan las cartas ofrecen algunas claves para entender los motivos y los posibles delatores. Estas pistas señalaban a miembros del Colegio Trilingüe y, posiblemente, a ciertos catedráticos del claustro universitario, lo cual dará pie a reflexionar sobre el papel que unos y otros jugaron en torno al proceso inquisitorial del bachiller Escribano. También resulta valiosa la información obtenida en los interrogatorios realizados durante las visitas que cada cierto tiempo se hacían al Colegio por parte de catedráticos designados para tal efecto. Juan Escribano asumiría un importante papel en la mayoría de estas visitas, ya que su celo por el Trilingüe se traducía en relatos detallados sobre la vida de dicha institución y de sus miembros. Paradójicamente, esta entrega traería consigo fatales consecuencias para el helenista.

\section{El Colegio Trilingüe y Juan Escribano}

La evolución histórica del Colegio Trilingüe estuvo ligada a la vida del bachiller Escribano, al menos durante sus primeras décadas de andadura ${ }^{13}$. El Colegio, en sus orígenes, estaba formado por doce colegiales becados: uno con funciones de vicerrector, que debía ser presbítero, más dos regentes de griego y hebreo, a los que se sumaban a nueve discentes: dos estudiantes de hebreo, tres de griego y cuatro retóricos. Además, existía otro regente de retórica que vivía anexo al Colegio, veinte porcionistas (que pagaban por su estancia), cuatro familiares y un cocinero. Tanto el vicerrector como los regentes se encargaban de la formación de los colegiales mediante la explicación de dos lecciones sobre sus respectivas áreas de conocimiento, aunque también se ocupaban de la educación moral y de la conducta de sus estudiantes ${ }^{14}$. La relación de los catedráticos del Trilingüe con la institución y sus miembros

11 La ausencia de investigaciones sobre los problemas inquisitoriales de Juan Escribano ha sido señalada por SAN JOSÉ LERA, J.: "Libros y lectura en los procesos inquisitoriales de los profesores salmanticenses del siglo XVI", en Vega Ramos, M. J. y NaKládaloví, I. (eds.): Lectura y culpa en el siglo XVI /Reading and guilt in the 16th century, Barcelona, Servei de Biblioteques de la Universitat Autónoma de Barcelona, 2012, pp. 63-92.

12 Las cartas se hallan en el Archivo Histórico Nacional (AHN), Inquisición, Cartas, leg. 3192. Los Libros de Visitas del Colegio Trilingüe recogen información muy interesante y de primera mano sobre su funcionamiento y sus integrantes, y se efectuaron con una frecuencia variable en el periodo que nos ocupa, de modo que podemos encontrar espacios desde un mes hasta un año entre una visita y otro. AUSA, Visitas Trilingüe, leg. 2134 (visitas 1560-1574) y AUSA, Visitas Trilingüe, leg. 2135 (visitas entre 1574-1588). Las signaturas de los diferentes Libros de Claustros se indicarán en las citas a pie de página.

13 La fundación del Colegio Trilingüe, a imitación del de Alcalá, fue ordenada por el visitador D. Diego Enríquez de Almansa, obispo de Coria, en 1550, aunque su apertura no tendría efectos hasta cuatro años más tarde. Véase LóPEZ RuedA, op. cit. (nota 9), pp. 87 y ss.

14 La profesora Ana Carabias realizó un interesante estudio sobre el desarrollo de esta institución. Véase CARABIAS Torres, A. M.: "Evolución histórica del Colegio Trilingüe de Salamanca: 1550-1812”, Studia Historica. Historia Moderna, 3 (1983), pp. 143-168. 
se basaba tanto en cuestiones académicas como personales. Así, Juan Escribano cobraba, según los estatutos del Colegio, 20.000 maravedís por ser regente de griego y realizar dos lecturas diarias. Éste enseñaba la cátedra de medianos en invierno de nueve a diez de la mañana y lecciones de gramática de dos a tres de la tarde, mientras que en verano lo hacía de ocho a nueve y de tres a cuatro respectivamente ${ }^{15}$. Por otro lado, la cohabitación de regentes, vicerrectores y colegiales en las dependencias del Trilingüe inevitablemente conllevaba la mezcla de los asuntos académicos con los privados, lo cual sería una fuente de continuos conflictos.

A lo largo de la vida del bachiller Escribano fueron constantes y casi unánimes las alabanzas proferidas por el claustro de profesores de la Universidad, tanto a su trabajo en el Colegio como a su persona. De estos testimonios y de los suyos propios se infiere que tenía un carácter reservado, entregado a sus estudios y a la denuncia de las irregularidades del Trilingüe. Precisamente la situación precaria del Colegio fue causada, principalmente, por la gestión nefasta de la mayoría de sus vicerrectores, los cuales, en connivencia con algunos colegiales y otros miembros de la Universidad, se despreocuparon de su funcionamiento y aprovecharon sus recursos en beneficio propio ${ }^{16}$. Entre ellos sobresalió Cristóbal del Río, que fue, sin duda, uno de sus peores administradores, y, como veremos, uno de los principales enemigos del regente de griego.

El bachiller Escribano asumió paulatinamente un importante papel -aunque a menudo en la sombra- en la defensa del Trilingüe, jalonado con algunos contactos indirectos con el Santo Oficio en los años previos a su encarcelamiento ${ }^{17}$. A resultas de ello, al mismo tiempo que ponía de manifiesto la gravedad de la situación del Colegio, paradójicamente se vio inmerso en una serie de acusaciones que culminaron con su proceso inquisitorial y encarcelamiento en Valladolid.

\section{El proceso inquisitorial contra Juan Escribano: su prisión en Valladolid}

En ausencia del documento del proceso inquisitorial del bachiller Escribano, hemos podido seguir algunas pistas de los casi veintiún meses que permaneció cautivo en las cárceles de Valladolid a través de las cartas que en el Tribunal de la Suprema Inquisición de Madrid recibían desde el Tribunal vallisoletano. Las primeras noticias sobre su proceso las conocemos por carta del Tribunal de Valladolid fechada a 19 de enero de 1575. En ella se hacía mención a que los licenciados Diego González y Diego Valcárcel, inquisidores de Valladolid, habían recibido desde el Tribunal de la Suprema en Madrid la autorización para comenzar el proceso contra el bachiller Escribano el día 15 del mismo mes ${ }^{18}$. Esto indicaría que, en su fase inicial, dicho

CARABIAS Torres, op. cit. (nota 14), p. 147; LóPez Rueda, op. cit. (nota 9), pp. 95-96

16 Sobre la pésima gestión de algunos vicerrectores en la primera década del Trilingüe en RuBio MuÑoz, op. cit. (nota 8); CARABIAS Torres, op. cit. (nota 14), pp. 145-158.

17 Los contactos de Juan Escribano con la Inquisición previos a su proceso se dieron en el contexto de la investigación contra las obras de Pierre de la Ramée y los interrogatorios de Fray Luis de León y Martínez de Cantalapiedra. En el primer caso fue interrogado sobre la lectura de las obras del Ramus, mientras que posteriormente sería preguntado como testigo en la defensa de sus colegas. Véase RuBio MuÑoz, F. J.: "La Universidad y el Santo Oficio: el silencio elocuente", en PAvón, A. (coord.): Libertades Universitarias en el mundo hispánico. Siglos XVI al XX, México, Instituto de Investigaciones sobre la Universidad y la Educación (IISUE) - Universidad Nacional Autónoma de México (UNAM) [en prensa].

18 Carta del Tribunal de Valladolid, fechada en 19 de enero de 1575 y recibida en Madrid el 22 de enero de 1575 , AHN, Inquisición, Cartas, leg. 3192, exp. 94. Indicaba Fernández Giménez que solía haber dos inquisidores 
proceso habría empezado probablemente por una denuncia o acusación, previa a su encarcelamiento, el cual habría tenido lugar en la primera quincena de enero ${ }^{19}$. Los libros de claustro de la Universidad de Salamanca no dan cuenta de este hecho; sólo aparecerían noticias indirectas hacia mayo de dicho año, cuando Juan de Villalobos fue designado regente de griego en sustitución de Escribano ${ }^{20}$.

Casi tres meses después, el 25 de agosto de 1575, desde Valladolid se notificó la recepción del "memorial que envió el señor Bernardo Temiño tocante a Juan Escribano" "21. Esto podría indicar que, hasta ese momento se había llevado a cabo una primera fase sumaria o inquisitiva, la cual era secreta para el sospechoso. Éste solía desconocer las acusaciones vertidas contra él debido a su aislamiento, lo que hacía difícil su defensa. En cualquier caso, el proceso había entrado en una fase intermedia; probablemente el memorial se refiriera a los interrogatorios de los testigos ${ }^{22}$. Las informaciones ulteriores que se contienen en las cartas hablarían, sobre todo, de las duras condiciones que Juan Escribano sufrió durante su estancia en las cárceles, las

en los tribunales, uno teólogo y otro jurista generalmente. Véase Fernández GiménEz, M. C.: "La sentencia inquisitorial". Manuscrits, 17 (1999), p. 121. El licenciado Diego González fue inquisidor en Valladolid durante los procesos contra el Arzobispo Carranza y contra los hebraístas salmantinos. Véase GutiérRez, C.: Españoles en Trento, Valladolid, 1951, pp. 258-260. Diego de Varcálcel Briceño fue inquisidor primero de Aragón antes de pasar a serlo de Valladolid en 1573. Véase Gómez Vozmediano, M. F.: "Fuentes para el estudio de la Inquisición conservadas en el Archivo Histórico de la Nobleza (Toledo) [en línea], III Simpósio Internacional de Estudos Inquisitoriais: novas fronteiras, Alcalá de Henares, Universidade Federal do Recôncavo da Bahia (UFRB), 2015, p. 16, nota 185, www3.ufrb.edu.br/simposioinquisicao/wp-content/uploads/2016/04/Miguel_ Vozmediano_1.pdf, [consulta: 28 de marzo de 2017].

19 No solía pasar demasiado tiempo entre el momento de la denuncia y el arresto del denunciado, de modo que ambos hechos sucedían previamente a la fase de indagación que daba comienzo en ese momento, como señalaba Tomás y Valiente con el ejemplo de Alonso de Alarcón, cuyo ingreso en prisión sucedió 3 días después de la denuncia. Véase Tomás y Valiente, op. cit. (nota 4), pp 33-34. Por otro lado, creemos que el proceso se inició por una denuncia debido mismamente a que es el tribunal de Valladolid el que parece iniciar el oficio, como se ve en la carta citada, seguramente incoado por la persona denunciante. No se trataría, pues, de una acusación, en donde el acusador formaba parte y debía aportar las pruebas, ni tampoco una inquisición (iniciada de oficio por el juez), si bien la ausencia del documento del proceso hace que no descartemos ninguna posibilidad. Véase FERNÁNDEZ GimÉneZ, op. cit. (nota 18), p. 123-124.

20 SÁnchez y SÁnchez, D. (ed.): Corpus documentale Universitatis Studii Salmantini, Salamanca, Caja Duero, 2004, vol. 2, p. 617. López Rueda menciona la fecha del 13 de enero como el día en que el regente de griego es encarcelado, pero no cita la fuente, aunque, como hemos visto, no iba desencaminado. También cita que, durante la ausencia de Escribano, Villalobos se haría cargo de una de las lecciones, mientras la otra fue encomendada al maestro Francisco Meneses, que era ya profesor de latín. Véase López RuEdA, op. cit. (nota 9), pp. 99-100. La única noticia sobre el ingreso del helenista en la cárcel de la Inquisición de Valladolid por esas fechas está contenida en una carta que Francisco de Salinas, catedrático de Música en Salamanca, envió a Arias Montano el 29 de enero de 1575, en la que señalaba que "esta semana embió aquí la Inquisición de Valladolid por un profesor de la lengua griega llamado Juan Escrivano, al parescer de todos muy buen christiano, y de los que bien entienden y uno de los que mejor agora saben en España todas tres lenguas y las artes liberales y la Philosophía y Teología, y el que mejor y más exquisitos libros tenía. No sabemos si el mal está en él o en los acusadores. Nuestro Señor ponga el remedio que conviene a él y a los maestros que allá están". Antonio Dávila, siguiendo lo dicho por Salinas, aseguraba que 23 de enero Escribano entraba en prisión, aunque por las cartas que hemos aportado debió suceder, probablemente, en la primera quincena de enero. Véase ARIAS Montano, B.: Correspondencia conservada en el museo Plantin-Moretus de Amberes, (edición a cargo de Antonio Dávila), Alcañiz-Madrid, Instituto de Estudios Humanísticos, 2002, vol. 1, pp. 185-186. Citado por SAN José LeRA, J. op. cit. (nota 11), p. 64.

21 Carta del Tribunal de Valladolid, fechada en 20 de agosto de 1575 y recibida en Madrid el 25 de agosto de 1575, AHN, Inquisición, Cartas, leg. 3192, exp. 150. Bernarndo Temiño fue uno de los inquisidores presentes en el proceso contra el arzobispo Carranza. Véase Menéndez Pelayo, M. Historia de los heterodoxos españoles, Madrid, CSIC, 1992, vol. 2, pp. 62-63.

22 Tomás y Valiente, op. cit. (nota 4), p. 21. El secreto se extendía con posterioridad a la sentencia, ya que al reo se le prohibía desvelar lo que había ocurrido durante su encarcelamiento. Véase FERNÁNDEZ GimÉNEZ, op. cit. (nota 18), p. 123; seguiremos a ambos autores para establecer las fases del proceso inquisitorial de Juan Escribano, así como a KAmEn, H.: La Inquisición española, Madrid, Grijalbo, 1972, caps. 9 "La Inquisición española: sus procedimientos" y 10 "La Inquisición española: proceso y condenación". 
cuales eran realmente penosas. Gaspar de Grajal, preso al mismo tiempo que Fray Luis, Cantalapiedra y Escribano, enviaba una carta el 6 de septiembre de 1575 a las autoridades inquisitoriales quejándose de la gravedad su enfermedad y suplicando que le trasladasen a otro lugar "con las guardas que vuestras mercedes gustasen para ello [...]; suplico que me den quien me sirva, pues [...] no es raçón que yo esté sin quien me pueda menear y limpiar"23. Tres días después, fallecía.

Parece que las muertes de Grajal y de otros presos inquietaron el ánimo de los inquisidores, o al menos les hizo replantearse un traslado de los reclusos ante la insalubridad de la cárcel. Así, veinte días después de que el maestro falleciera, en carta enviada desde Valladolid, se notificaba que "el bachiller Juan Escribano y Fray David y Alexandre Montero, morisco, se han sacado fuera destas cárceles para curarse, porque en ellas corrían peligro de la vida según el médico [...]”24. Juan Escribano, que había caído enfermo como otros encarcelados, fue seguramente enviado al Hospital del Esgueva para su recuperación, como parece ser que ocurrió con algunos reos que murieron poco después. Y es que la situación fue haciéndose tan extrema que las muertes no cesaban, a tal punto que, el 30 de septiembre, los inquisidores Diego González y Andrés de Álava notificaron a Madrid las circunstancias críticas en que vivían no sólo los presos, sino el personal de la cárcel inquisitorial:

Por la del 24 del pasado [septiembre] significamos a vuestra señoría cómo avíamos sacado destas cárceles al bachiller Juan Escribano, y Alexandre Montero, morisco, y a Fray David, por sus graves enfermedades, y el fray David murió anoche, día de San Miguel, en el Hospital de Esgueva, a donde se puso, y certificamos a vuestra señoría que todos los demás presos están muy malos y les dan unas calenturas con modorra tan peligrosa que si no se sacan, morirán, y los sanos de fuera, que hemos metido para servir a los enfermos de las cárceles, ansí mismo caen luego de la misma enfermedad [...]. Vuestra señoría sea servido de mirar el remedio que podrá aber porque es mucha lástima ver los enfermos desta casa y que sin esperanza de salud está ninguno de ellos $[\ldots]^{25}$.

El testimonio conmovedor de los responsables de la cárcel surtió el efecto deseado, y desde Madrid se ordenó poner remedio consultando el parecer de cuatro médicos para que los presos fuesen curados y sus causas se pudieran continuar antes de que se murieran. El 15 de octubre se adjuntó la opinión de los galenos acerca del estado de las cárceles, y todos coincidieron en su falta de higiene por las humedades, la proximidad del Esgueva y los defectos constructivos ${ }^{26}$. Finalmente, el 29 de octubre se dio solución al cambiar la ubicación de la cárcel a "su antigua y primera morada", por lo tanto, se trasladaba de la calle de los Moros -las llamadas "cárceles nuevas"- a la calle de Pedro Berrueco, donde habían permanecido hasta 1559, razón

23 De la Pinta Llorente, op. cit. (nota 5, 1935), p. 479.

24 Carta del Tribunal de Valladolid, fechada en 24 de septiembre de 1575 y recibida en Madrid el 28 de septiembre de 1575, AHN, Inquisición, Cartas, leg. 3192, exp. 162.

25 Carta del Tribunal de Valladolid, fechada en 30 de septiembre de 1575 y recibida en Madrid el 3 de octubre de 1575, AHN, Inquisición, Cartas, leg. 3192, exp. 164. Andrés de Álava, colegial de San Bartolomé, había sido inquisidor de Granada, y llegaría a sería inquisidor de Toledo y de la Suprema de Madrid, falleciendo en 1607. Véase Pizarro Llorente, H.: Un gran patrón en la corte de Felipe II. Don Gaspar de Quiroga, Madrid, Universidad Pontificia de Comillas, 2004, pp. 247-249.

26 Carta del Tribunal de Valladolid, fechada en 12 de octubre de 1575 y recibida en Madrid el 15 de octubre de 1575, AHN, Inquisición, Cartas, leg. 3192, exp. 171. 
para pensar, a diferencia de lo que se sostiene, que podría ser el lugar donde también estuvo Fray Luis de León, preso por esas fechas. ${ }^{27}$

El proceso de Juan Escribano sufrió otro cambio durante el mes de sucesivo, pasando probablemente de la fase probatoria hacia lo que debería haber sido la fase final. Sin embargo, el 7 de noviembre de 1575 el Tribunal de Valladolid enviaba "el proceso del bachiller Juan Escribano, regente del Trilingüe, botado en discordia, para que siendo vuestra señoría servido nos mande lo que se le debamos hacer [...]"28. Esto implicaba que, al no ponerse de acuerdo sobre la sentencia, se solicitaba al Tribunal de la Suprema en Madrid que resolvieran la cuestión, lo que significaría, a la postre, que el tiempo de Escribano en la cárcel se alargaría más de lo esperado.

Ante el estancamiento del proceso se abrieron nuevas diligencias, encaminadas a recoger más pruebas. Algunas de ellas las conocemos por carta enviada desde Valladolid el 16 de noviembre. En referencia a una orden recibida desde Madrid el día 12 de dicho mes "en la que vuestra señoría nos advierte que se obieran de secretar sus papeles [de Juan Escribano], todos, así se hizo, y por entonces no pareçió que dellos resultase alguna cosa contra él, y ésta es la causa porque no se pusieron en su proceso" 29 . Por tanto, el registro de su biblioteca y sus documentos personales en principio no aportó ninguna prueba incriminatoria para culpar a Escribano de la acusación que pesaba sobre él. También se ordenó interrogar a otro testigo, concretamente "a Francisco Gómez, cura de la Magdalena, a quien [Juan Escribano] había nombrado por testigo en las defensas, y no se examinó porque era muerto, y ansí consta en su proceso por carta del comisario, y está apuntado en la margen en la pregunta donde le nombra por testigo" "30. La muerte de uno de los testigos, que, como veremos, podía haber sido importante en la defensa del regente Escribano, habría dificultado seguramente el ritmo ya de por sí lento del proceso contra el helenista. No obstante, la mención a este testigo junto con las líneas que siguen a continuación nos dan la clave acerca de los cargos que podrían haberse presentado contra el bachiller. Así, la carta finalizaba diciendo que "sobre lo que el reo dixo çerca de la Vulgata, lo verá y calificará Fray Domingo Ibáñez con otros como vuestra señoría manda [...]”31.

27 Carta del Tribunal de Valladolid, fechada en 29 de octubre de 1575, AHN, Inquisición, Cartas, leg. 3192, exp. 180. Este testimonio es más relevante de lo que parece, puesto que la ubicación de las casas inquisitoriales en Valladolid varió a lo largo del siglo XVI. La información disponible hasta ahora situaba su emplazamiento en la calle de Pedro Berrueco, en el actual Palacio de los Escudero-Herrera, hasta 1559; era lo que denominó "la Inquisición Vieja”. A partir de esa fecha el Santo Oficio se trasladaba a las casas pertenecientes a los González de León, formalizándose en 1572 la compra de las mismas, en donde permanecieron hasta su incendio en el siglo XIX. Fernández Martín situaba a Fray Luis en las “cárceles nuevas", y no en sus predecesoras; sin embargo, hemos visto que en 1575 se producía el traslado de la prisión -seguramente temporal- a su emplazamiento anterior, con lo cual, la actual calle Fray Luis de León de Valladolid (antigua calle Pedro Berrueco) tendría justificada su denominación. Véase Fernández Martín, L.: "La casa de la Inquisición de Valladolid". Investigaciones históricas, 10 (1990), pp. 191-192

28 Carta del Tribunal de Valladolid, fechada en 7 de noviembre de 1575 y recibida en Madrid el 9 de noviembre de 1575, AHN, Inquisición, Cartas, leg. 3192, exp. 184.

29 Carta del Tribunal de Valladolid, fechada en 16 de noviembre de 1575 y recibida en Madrid el 21 de noviembre de 1575, AHN, Inquisición, Cartas, leg. 3192, exp. 186. El secuestro de bienes iba aparejado al momento del encarcelamiento, por tanto, se refiere a un hecho que debió ocurrir al poco de que Juan Escribano ingresase en prisión. Véase FERnÁNDEZ GimÉnEZ, op. cit. (nota 18), p. 126.

30 Ibidem.

31 Carta del Tribunal de Valladolid, fechada en 16 de noviembre de 1575 y recibida en Madrid el 21 de noviembre de 1575, AHN, Inquisición, Cartas, leg. 3192, exp. 186. Se refería, sin duda, al maestro Fray domingo Báñez, dominico, que poco después sería catedrático de Teología nominal en la Universidad de Salamanca. Véase Beltrán de Heredia, V.: Miscelánea Beltrán de Heredia, Salamanca, Editorial OPE, 1972, vol. 3, pp. 7-39 para sus datos biográficos, y 40-110 para su relación con la Inquisición y con otros catedráticos procesados como Gaspar de Grajal o Fray Luis de León. 
Es decir, que, al menos, una de las acusaciones había sido algún supuesto comentario heterodoxo contra la Vulgata, la versión oficial de la Biblia.

¿Existe alguna prueba de tal comentario? Hemos de mirar, en este caso, hacia el proceso contra Martínez de Cantalapiedra ${ }^{32}$. En él, el bachiller Escribano fue llamado a declarar como testigo acerca de la validez de los textos hebreos "porque de otra manera los originales serían superfluos" ${ }^{\prime 3}$. A pesar de que no conocemos si tal declaración llegó a efectuarse, lo que sí parece indicar es que el regente de griego estaba bajo sospechas y siguió el mismo camino que sus colegas hebraístas. En este sentido, todo parece indicar que los motivos oficiales fueron aparentemente teológicos, al igual que había ocurrido con Fray Luis, Cantalapiedra y Graja ${ }^{34}$. De todos modos, esta hipótesis entraría dentro de las causas formales del proceso, pero aún queda por ver el trasfondo de las mismas. A ello volveremos después, en las reflexiones acerca de los posibles factores que precedieron al proceso contra el helenista.

Desde noviembre de 1575 hasta junio de 1576 no volvemos a tener novedades sobre el estado de Juan Escribano, pero suponemos que en ese tiempo el proceso continuaba parado, sin resolverse. Esta excesiva demora también era percibida por el Tribunal de Valladolid, que apremiaría escribiendo a Madrid al respecto. Así, el 20 de junio de 1576 nuevamente se enviaba el proceso votado en discordia ${ }^{35} \mathrm{y}$ en cartas posteriores se insistía hasta en tres ocasiones en que se diera una solución. Concretamente, el 1 de agosto se recibieron en Madrid dos cartas desde el Tribunal de Valladolid. La primera, suplicando "a vuestra señoría que determine con la brevedad que fuese lugar, porque ha días que [Juan Escribano] está preso", y la segunda pidiendo que se remitiera "el proceso del bachiller Juan Escribano que los días pasados se envió a este Sancto Consejo"36.

Parece ser que la Suprema hacía caso omiso a los requerimientos del Santo Oficio vallisoletano, pues el 15 de septiembre se volvía a mencionar el asunto, implorando que se mandase "lo que se ha de hacer en el negocio de Juan Escribano, cuyo proceso dende mediado junio está votado y se envió a ese Sancto Consejo con carta del veinte del mismo, y padesce con mucha pobreza y miseria el susodicho en las cárceles" ${ }^{37}$. Esta precaria situación por fin se resolvió al iniciarse octubre de 1576, en donde se notificaba la recepción en Valladolid de "dos cartas [...] con el proceso del bachiller Juan Escribano, y se hará en él lo que vuestra señoría manda" ${ }^{38}$. Las cartas sobre el bachiller concluyen aquí, por tanto, Escribano quedó libre entre el 6, fecha de

32 Juan Escribano aparece en el círculo de Cantalapiedra, el cual, durante su proceso, afirmaba conocer al helenista, calificándolo como "humanista" y como "bonissimo hombre". Véase De la Pinta Llorente, op. cit. (nota 5, 1956), p. 211.

33 De la Pinta Llorente, op. cit. (nota 5, 1956), pp. 275-276. No obstante, no aparece el resultado de dicho interrogatorio a Juan Escribano; quizás no llegó a realizarse.

34 Éstos fueron acusados, entre otras cosas, de haber dicho que la versión de la Vulgata de la Biblia contenía elementos erróneos y que podría hacerse traducciones mejores. Véase BARRIENTOS, J.: "El temor a la Inquisición en la Universidad de Salamanca en tiempos del proceso de Carranza", Anuario de Historia de la Iglesia, 18 (2009) p. 184.

35 Carta del Tribunal de Valladolid, fechada en 20 de junio de 1576 y recibida en Madrid el 23 de junio de 1576 , AHN, Inquisición, Cartas, leg. 3193, exp. 55.

36 Carta del Tribunal de Valladolid, fechada en 1 de agosto de 1576 y recibida en Madrid el 4 de agosto de 1576 , AHN, Inquisición, Cartas, leg. 3193, exp. 76; Carta del Tribunal de Valladolid, fechada en 4 de agosto de 1576 y recibida en Madrid el 4 de agosto de 1576, AHN, Inquisición, Cartas, leg. 3193, exp. 78.

37 Carta del Tribunal de Valladolid, fechada en 12 de septiembre de 1576 y recibida en Madrid el 15 de septiembre de 1576, AHN, Inquisición, Cartas, leg. 3193, exp. 96.

38 Carta del Tribunal de Valladolid, fechada en 6 de octubre de 1576, AHN, Inquisición, Cartas, leg. 3193, exp. 101 . 
la última carta, y el 27 de octubre de dicho año en que se reincorporaría al claustro universitario ${ }^{39}$.

\section{Sobre las causas del proceso inquisitorial}

"Vivimos tiempos difíciles en los que no podemos callar ni hablar sin peligro"40. La célebre frase de Vives recoge, en esencia, el infortunio por el que pasó el bachiller Juan Escribano, así como una idea de los motivos que pudieron llevarle ante la Inquisición. Con las noticias indirectas obtenidas de las cartas enviadas por el Tribunal de Valladolid al de la Suprema Inquisición de Madrid se ha podido reconstruir, en la medida de lo posible, algunos de los avatares por los que Juan Escribano pasó durante el tiempo que estuvo encarcelado. Por otro lado, también han aportado información sobre el desarrollo de su proceso, de cómo fue votado en discordia y de algún testigo llamado a defenderle. Toca ahora reflexionar sobre un aspecto de igual importancia: los delatores que le denunciaron ante la Inquisición y las posibles causas.

El contenido de la sentencia definitiva en el proceso del bachiller Escribano se conoce gracias a la "Relaçión de las causas despachadas por este Santo Oficio", un sumario que recogía anualmente todos los dictámenes del Tribunal, en este caso entre el 15 de noviembre de 1575 al 15 de diciembre de 1576. Entre ellos también se encuentra la resolución del juicio a Fray Luis de León. En ella, en novena posición, dentro de los "Penitenciados fuera de auto", se señalaba que

el bachiller Juan Escribano, colegial trelingüe en Salamanca, de hedad de cincuenta años, fue testificado de las proposiciones que vuestra señoría tiene vistas y, sustanciado su negocio, fue botado en discordia y vuestra señoría mandó que en la sala de la audiencia de este Sancto Oficio se le diese su sentencia y abjura de levi y fuese reprehendido grandemente y declarase las proposiciones, ansí las que estava testificado como las que se hallaron en sus papeles en el Colegio Trelingüe ante las personas que le fue señalado ${ }^{41}$.

Recordemos que las cartas, aun parcas en datos, apuntaron hacia cuestiones en torno a la Vulgata en donde Juan Escribano habría tomado parte. Ésta era la denuncia oficial ante el Santo Oficio de quienes le habían señalado. Pero tan importante como la denuncia eran sus instigadores, los cuales parecen estar relacionados con el Colegio Trilingüe.

\subsection{Enemigos en el Trilingüe}

Si leemos detenidamente el contenido de la sentencia que nos aporta la nota de las relaciones de causas, podremos comprobar que tiene una parte bastante genérica. Se trata de la abjura de levi, que se realizaba cuando el fiscal no había probado la acu-

39 Beltrán de Heredia, op. cit. (nota 3), pp. 309-311.

40 Citado por Alcalá, Á.: "Peculiaridad de las acusaciones a fray Luis en el marco del proceso a sus colegas salmantinos", en GARcía de la Concha, V. y SAN José Lera, J. (eds.): Fray Luis de León. Historia, humanismo y letras, Salamanca, Ediciones Universidad de Salamanca, 1996, p. 65.

${ }_{41}$ Carta del Tribunal de Valladolid, fechada en 20 de diciembre de 1576 y recibida en Madrid el 23 de diciembre de 1576, AHN, Inquisición, Cartas, leg. 3193, exp. 120, s/fol. Véase LóPEz RuEdA, op. cit. (nota 9), p. 100. 
sación, de modo que el Tribunal absolvía al reo porque las sospechas de herejía que pesaban sobre él eran leves ${ }^{42}$. A continuación, hay otro fragmento de la sentencia que entra en contradicción con lo que conocemos por las cartas: que entre sus papeles no se había encontrado nada incriminatorio, y que por tanto no se adjuntaban al proceso. Frente a ello, ahora parece ser que algunas de las supuestas proposiciones de las que fue acusado "se hallaron en sus papeles en el Colegio Trelingüe". ¿Alguna "mano negra" del Trilingüe los había facilitado o alterado? ¿Estaban el o los delatores de Escribano entre aquellos que tenían alguna relación con el Colegio?

Los testimonios de Juan Escribano, recogidos en las múltiples visitas que se realizaron al Colegio Trilingüe, muestran a un hombre crítico con la mayoría de los vicerrectores, ya que de su controvertida gestión dependió la trayectoria fluctuante de dicha institución. En este sentido, podría decirse que las relaciones del regente de griego con los vicerrectores fueron, en general, distantes, aunque siempre acordes con la mejor o peor actuación de éstos al frente del Trilingüe. La situación complicada por la que pasaba el regente de griego intramuros del Trilingüe había repercutido en la salud del catedrático y, a posteriori efectivamente fue, en palabras del propio Escribano, una de las causas de su encarcelamiento por el Tribunal de la Inquisición $^{43}$. Precisamente el 15 de julio de 1574, meses antes de ser enviado a prisión, el bachiller solicitaba al claustro irse a vivir fuera del Colegio ya que "ahora con mis indisposiciones me hallo mal en el Colegio. Suplico a vuestra señoría, pues con otros se ha hecho, que fuera se me dé una comodidad con que pueda pasar"44. Aunque argumentaba hallarse enfermo, y seguramente no sería incierto, quizás tras tanta urgencia por marcharse a vivir fuera del Trilingüe había un augurio de lo que le sucedería si permanecía en él, como así ocurrió pocos meses después ${ }^{45}$.

Suponer que los culpables de llevar a Juan Escribano a la cárcel de la Inquisición provinieran del Trilingüe no es algo sin fundamento, sobre todo si tenemos en cuenta las palabras del regente de griego tras recobrar la libertad. Así, tras haber "salido libre para poder tener cualquier cargo y oficio que se le encomendase", el bachiller pidió la reincorporación a la Universidad el 27 de octubre de 1576, momento en el que volvía a hacer hincapié en su deseo de no vivir entre los muros del Trilingüe:

Muy ilustres señores: yo he llegado aquí después de esta mi infeliz jornada que caminé más por ajena culpa que por mía. Y como acostumbrado a recibir mercedes de vuestra señoría, vuelvo a que use conmigo su liberalidad, de la cual tengo ahora más necesidad por dos cosas. La una para me emplear en su servicio sin anexión al Colegio, al cual tengo por fatal para mí y [de] donde tanto mal me vino. La otra en me ayudar con alguna cosa para cumplir algo de lo mucho que debo. Lo cual todo, así Dios me salve, entiendo que me vino por el bueno celo que siempre tuve

\footnotetext{
$42 \quad$ FERnÁNDEZ GiméneZ, op. cit. (nota 18) p. 171 y ss.

43 No en vano, el regente tenía una salud delicada que en ocasiones le impidió ejercer sus funciones docentes o cenar en el refectorio. Así lo aseguraba el 9 de junio de 1562, cuando dijo "que çena en su cama por ser muy tenprana la cena del Colegio y no tener estómago para cenar a aquella hora por ser enfermo dél”. AUSA, Visitas Trilingüe, leg. 2134, fol. 23 v. También fue palpable por sus colegas del claustro en varias ocasiones, como el 8 de noviembre de 1565 cuando se le exime de pagar las multas por faltar a sus lecciones, "atento que es hombre enfermo como por su aspecto consta". AUSA, Claustros, leg. 34, fol. 159 r. Véase SÁnchez y SánChEZ, op. cit., (nota 20), p. 542.

44 Beltrán de Heredia, op. cit. (nota 3), p. 290.

45 Por el contrario, el claustro desoyó sus súplicas de trasladarse a otro lugar. Ibidem, p. 291. López Rueda aprecia también que tras las indisposiciones podría esconderse alguna desavenencia en el Trilingüe. Véase LóPEZ RuEDA, op. cit. (nota 9), p. 99.
} 
a las cosas de la Universidad, a la cual he servido quince años largos antes que me prendiesen. Y con esto me tendrá vuestra señoría obligado el resto que me queda de vida para servir. Juan Escribano ${ }^{46}$.

Directamente señalaba al Colegio Trilingüe y, por ende, sus integrantes o alguien relacionado con él, como los verdaderos culpables de su delación. Además, vinculaba su buen hacer en esta institución con su prisión, de lo cual puede entenderse que sus acusadores fueron movidos precisamente porque Escribano había defendido los intereses del Colegio denunciando ante los visitadores a aquellos que lo descuidaban y se aprovechaban de sus recursos.

Llegados a este punto, se hace necesario traer a colación la animadversión que el vicerrector del Trilingüe, Cristóbal del Río, tenía hacia Juan Escribano, puesta de manifiesto en las acusaciones que el primero, junto con el colegial Andrés Osorio, hicieron contra el helenista. Éstas, lanzadas a finales de 1573, se basaban en informaciones muy difusas sobre supuestas faltas doctrinales del bachiller en relación a la confesión y la comunión, así como una crítica a su carácter introspectivo y, de paso, levantar sospechas por la posibilidad de ocultar algo en sus aposentos ${ }^{47}$. La causa última de dichas acusaciones habría sido la venganza por un desencuentro en el refectorio, en el cual Escribano habría acusado de tiranía el vicerrector al pretender este último que los colegiales nuevos pagasen la patente o propina a los veteranos ${ }^{48}$. Pero realmente la animadversión, como el propio Escribano diría, venía de lejos.

Ante estas acusaciones, el visitador León de Castro levantó cargos contra el regente de griego, los cuales fueron desmentidos y, aparentemente, no se tomó ninguna medida contra él más allá de una reprimenda. Sin embargo, la sombra de la duda quedó presente, $\mathrm{y}$, consciente de su soledad en el Colegio y de que todo provenía de su mala relación con el vicerrector del Río, el helenista realizó una declaración de su puño y letra que entregó directamente a los visitadores. En ella denunció el verdadero origen de las acusaciones vertidas contra su persona, en el marco de una confabulación hecha por el vicerrector y su camarilla para difamarlo y ocultar los graves sucesos que tenían lugar dentro del Trilingüe. Juan Escribano sostenía que sus enemigos eran tres o cuatro colegiales que habían sido expulsados en la visita anterior y, "sospechando que yo avía sido y mi dicha parte para que ellos fuesen ansí castigados, se quisieron vengar de mí en matar al vicerrector Christóval del Río, que al presente es, el qual los tenía y tiene por amigos, para que dixese de mí [...]"49. Por tanto, un primer motivo habría sido la venganza de aquellos que consideraron a Escribano como culpable de sus represalias, al haberse quejado de su comportamiento ante los visitadores. Ellos habrían intentado matar al propio vicerrector para inculpar a Escribano, aunque no parece que en las fuentes haya quedado reflejado este hecho.

${ }_{46}$ AUSA, Claustros, leg. 45, fol. 163 v y ss. Esta vez el claustro sí accede a sus peticiones "atento que no era ni es su voluntad estar dentro del Colegio como antes estaba, donde se le daba casa y comida, se le diese el equivalente fuera de él [...] cincuenta mil maravedís en cada un año: los treinta mil que antes se le daban e los veinte mil maravedís por la casa e comida [...] Véanse Beltrán de Heredia, op. cit. (nota 3), pp. 309-311 y LóPEZ RuEDA, op. cit. (nota 9), p. 101.

47 AUSA, Visitas Trilingüe, leg. 2134, s/fol. Véase Rubio MuÑoz, op. cit. (nota 8).

48 Cristóbal del Río declaraba que "Juan Escribano, regente de griego, dixo que no convenía que se hiziese [la patente] estorvandolo y diciendo que era gran tiranía y entonzes este declarante le respondió que no anduviese con él en puntas porque le haría maldezir el día en que nació e que el dicho Juan Escribano dixo que daría cuenta dello en la visita e que le haría echar del colegio o sobre ello iría al Consejo e se quexaría de lo que la Universidad hazía[...]. AUSA, Visitas Trilingüe, leg. 2134, s/fol.

49 AUSA, Visitas Trilingüe, leg. 2134, s/fol. 
No obstante, no termina ahí. El regente prosigue diciendo que

a este Christóval del Río desearon ellos mucho por vicerrector porque tratava mucho con ellos, y es hombre que negocia por presentes [...] pues pretendiendo él de andar al gusto de los colegiales que ay en casa y dexándoles salir con todos sus gustos, y viendo que a mí me parecía mal y que gruñía [...] y que a mí sólo tenía por testigo si viniese visita, me dixo de mí a él que si él salía de casa que me avía de costar a mí caro; y para arraigarse tiene granjeado al maestro Francisco Sánchez [de las Brozas] cuyo deudo es Osorio, colegial hebreo deste Colegio con el qual quiere autorizar sus cosas y éste está muy sentido de mí porque, quedando puesto por vice [sic] vicerrector en las continuas ausenctias del dicho Ríos, yo no baxo al refectorio por ver la desorden que anda y [...] el dicho Osorio, collegial hebreo, se mancomuna con este vicerrector para me perseguir $[\ldots]^{50}$.

Cristóbal del Río, por tanto, parecía controlar las relaciones del Colegio a través de sobornos y del colegial Andrés Osorio, que además era familiar de El Brocense y, además, había sido el único estudiante que acusó de las mismas faltas doctrinales a Escribano ${ }^{51}$. Todos ellos aparecen, según el helenista, como sus adversarios, de tal modo que su aislamiento provenía no sólo de su carácter discreto sino también de vacío que el vicerrector le hacía "vedándome que no fuese al aposento de nadie, aunque fuese sobre caso de estudios y diciendo de mi mal públicamente en el refectorio" 52 . El helenista, ante esta situación, no fue partícipe de las intrigas del vicerrector y sus secuaces, razón por la que

ellos dizen de mí solamente lo que les parece que pueden dañarme sin tener causa para sospechar mal. Yo no les daño por tratar más con mis estudios, y ansí todo lo que estos dixeren o los que salieron del colegio y fueron castigados por la Universidad, y el maestro Francisco Sánchez [de las Brozas, catedrático] de prima, por lo que yo diré si fuere menester, recuso por contrarios y que por vengarse de mi me levantarán agrabio $[\ldots]^{53}$.

La indefensión en la que se encontraba Juan Escribano facilitaba la labor a sus enemigos, puesto que "por estar muchas vezes indispuesto y, quando no lo estoy, ocuparme solo en mis estudios y en mi oficio y alguna lectio que leo a algunos amigos, trato con pocos maestros y doctores y casi no me conocen, ni rector ni casi visitadores; esto les da ánimo de poder salir con qualquier mentira [...]" ${ }^{154}$. A esta vulnerabilidad se suma la decepción de Juan Escribano con la Universidad, la cual no podía ser mayor. Algunos colegiales le habían comentado la actitud descomedida del vicerrector, pero

50 AUSA, Visitas Trilingüe, leg. 2134, s/fol.

51 Hemos de recordar que la mala relación de Juan Escribano con El Brocense vendría de lejos a juzgar por las acusaciones que el primero hizo sobre el segundo en el proceso contra las lecturas de Pierre de la Ramèe. Véase De la Pinta Llorente, M. A.: "Una investigación inquisitorial sobre Pedro Ramus en Salamanca", Religión y cultura (PP. Agustinos), 24 (1933), p. 242; RuBIo MuÑOZ, op. cit. (nota 17).

52 AUSA, Visitas Trilingüe, leg. 2134, s/fol.

53 Ibidem.

${ }^{54}$ Ibidem. No obstante, esto contrasta con las alabanzas que en el claustro se hacían hacia su labor y su persona. 
viendo que la Universidad lo dexa, yo también me hago sordo aunque ahora está casi desbaratada la disciplina y modestia casi de todo el Colegio, cuyo fin ansí de colegiales como de vicerrector es aprovecharse lo mejor que pueden desta hazienda de la Universidad y estar mal con quien a esto no les ayuda ${ }^{55}$.

La vinculación entre el proceso inquisitorial y el Trilingüe hecha públicamente por el mismo Escribano en su reincorporación a la Universidad parece que iba tomando forma. Dada la alta estima, irónicamente hablando, que le tenían dentro del Colegio, lo que parecía un hecho aislado, un suceso intramuros del Trilingüe, sería el detonante de una persecución que acabaría tristemente. El bachiller de griego, consciente de ello, intentó cubrirse las espaldas por lo que podría sucederle, advirtiendo a los visitadores que

como anda ahora el negotio de Inquisitión vivo y que prenden a muchos y de la cibdad y Universidad han preso algunos, parecioles que, acumulando una mentira con otra inqueriendose al número, que serían fácilmente creídos con qualquiera probança y, con lo que ellos tenían forjado, a lo menos me moverían infamia en ponerlo en controversia ya que otra cosa no pudiesen ${ }^{56}$.

En la misma declaración el helenista acusaba directamente al vicerrector de esta campaña difamatoria cuyos motivos eran, precisamente, distraer a los visitadores de su pésima gestión. Según el profesor de griego, un colegial que se había metido a fraile le había avisado de que

muy particularmente se le tome cuenta a vicerrector de si ha contado a la Universidad sus muchas ausentias y de los familiares que consigo ha llevado y de colegiales y muchos moços y mochachos que ha tenido aquí en diferentes tiempos, porque él no dava las quentas a firmar a los veedores como se suele hazer, y de su jugar y caçar y caminar y apostar largo en cátedras se puede sospechar algo $[\ldots]^{57}$.

Así lo recordaría el propio Escribano en la siguiente visita, iniciada el 2 de julio de 1574, cuando aseguraba que un tal Campo, familiar, se había ido del colegio un año antes "blasfemando de los hurtos que se haçían en el dicho Colegio"58. Poco se hizo al respecto, lo cual es, cuanto menos, sospechoso. El vicerrector continuó en su puesto, y, según parece, no cesó en su connivencia con algunos colegiales y en sus prácticas fraudulentas. En el verano de 1574, Juan Escribano se quejaba del desgobierno del Colegio, en donde algunos colegiales estudiaban otras disciplinas fuera de él, sumado al temor por los tejemanejes entre el vicerrector y Palacios, familiar y despensero del Trilingüe, en tanto que

los vehedores no asisten al pesar de la carne, espeçialmente Hurtado que es vehedor, entre el qual e Antonio Gómez e Palaçios, el despensero, ay partycular

\section{Ibidem.}

Ibidem.

57 AUSA, Visitas Trilingüe, leg. 2134, s/fol. La falta de control en la economía del Trilingüe también había sido denunciada en otras ocasiones por algunos colegiales y por el propio Escribano. Véase AUSA, Visitas Trilingüe, leg. 2134 , fols. 7 y 10 .

58 AUSA, Visitas Trilingüe, leg. 2135, fol. 10 v. 
familiaridad e monipodio [sic] e que estos dos colegiales entran a comer después de todos e que entran en la despensa e se ençierran con el despensero, lo qual este testigo e los demás an entendido y entienden ser perjuiçio de la comunidad ${ }^{59}$.

El tal Palacios debió ser un personaje bastante conflictivo, ya que Escribano "fue preguntado si el dicho Palaçios fuera de sisar en la dicha despensa si tiene otro viçio; dixo que este testigo a hoydo dezir en el dicho Colegio a personas que no se le acuerdan que se toma de vino" ${ }^{\circ}$.

Ante estas irregularidades parece que los visitadores reaccionaron, mandando al vicerrector que expulsase a los colegiales díscolos y a Palacios, despensero; pero por la visita siguiente (9 de agosto de 1574) Juan Escribano y otros colegiales dieron cuenta de cómo Cristóbal del Río - por cierto, ausente una vez más- no había cumplido tal orden ${ }^{61}$. Además, Palacios no sólo había permanecido en el Colegio durante un mes, sino también se había intentado vengar de Juan de Villalobos, colegial y veedor de las cuentas del Colegio, presumiblemente porque se había quejado de que "no le an dado las quentas para firmar [...] e que una vez, abrá un año poco más o menos, se las mandó firmar todas juntas el vizerrector e que este testigo hizo escrúpulo dello e que con todo las firmó" 62 . A ello añadía que "el despensero no compra por junto los alimentos aunque el vicerrector le da dinero y así el despensero debe dinero al dicho vizerrector, [...] quatro o seis mil maravedís e que no sabía en que se le debían y do si no era en prestar aquí e allí" $"$.

La situación se había hecho insostenible, y los visitadores tomaron la determinación de nombrar a Juan Escribano como vicerrector en ausencia de Cristóbal del Río, multando a este último, pero sin llegar a destituirle ${ }^{64}$. Esta decisión, envuelta en alabanzas y lisonjas hacia el profesor de griego, fue un dardo envenenado que avivó el odio de sus enemigos. A resultas de ello, el helenista fue el encargado además de ejecutar las expulsiones de algunos conocidos que no pertenecían al Trilingüe pero que vivían a costa del Colegio con la anuencia del vicerrector. Entre ellos estaban el sobrino del vicerrector, el hermano de Andrés Osorio, (uno de sus acusadores) y el hermano de Palacios, despensero ${ }^{65}$. Parece que Escribano ejecutó la sentencia, aunque el 2 de septiembre reaparecería de nuevo el vicerrector Cristóbal del Río apelando a que, debido a su ausencia, no había podido defenderse ${ }^{66}$. Nada volvió a saberse del asunto puesto que las visitas al Trilingüe se detienen hasta el 2 de febrero del año siguiente, al poco de que Juan Escribano entrase en prisión.

La tensión entre el vicerrector incompetente y el regente cumplidor estaba en un momento crítico, y el desenlace no tardaría en llegar. La influencia del vicerrector del Río fue tal que aun permaneció un año más en el cargo, hasta septiembre de 1575 , con Escribano ya entre rejas. Su vicerrectorado no pudo terminar de peor forma: tras el encarcelamiento del regente de griego, Cristóbal del Río estuvo preso

\section{Ibidem.}

Ibidem.

${ }^{61}$ AUSA, Visitas Trilingüe, leg. 2135, fol. 21 v. Las ausencias de Cristóbal del Río eran conocidas por todos. Así, Pedro Hurtado, colegial, declaraba que "el viçerector haze ausencia de la ciudad [...] que una vez fue a Burgos, e otras a Valladolid, e otras dos a cazar". Véase AUSA, Visitas Trilingüe, leg. 2134, fol. 14 r.

62 AUSA, Visitas Trilingüe, leg. 2135, fol. $22 \mathrm{r}$

63 AUSA, Visitas Trilingüe, leg. 2135, fol. 22 r.

${ }_{64}$ AUSA, Visitas Trilingüe, leg. 2135, fol. 24 r.

65 AUSA, Visitas Trilingüe, leg. 2135, fol. $24 \mathrm{v}$

66 AUSA, Visitas Trilingüe, leg. 2135, fol. 25 v. 
en las cárceles universitarias al destaparse el fraude que el preceptor de griego había denunciado al final de su declaración casi dos años antes ${ }^{67}$. Según el testimonio de Escribano, así como por los propios hechos, parece que Cristóbal del Río era un personaje bien conectado con algunos miembros del claustro universitario ya que, a pesar de sus desmanes, no había sido destituido. Además, contaba con el favor de ciertos catedráticos a través del uso de los recursos del Trilingüe y realizando prácticas de dudosa honestidad. De esta manera, Juan Escribano en la declaración que envió a los visitadores en 1573 no escatimó en detalles sobre

un hombre que tan mal haze su oficio y que haze más daño con el mal exemplo de cada día yéndose a caça y a jugar y otras ausentias de más tiempo, y dezir mil groserías por ser idiota y no saber leer; de lo qual se podrá todo hazer verdadera informatión, atreviéndose a que tiene prendados a los collegiales [...] y a los vecinos con jugar con ellos y andarse en cuerpo hasta las casas que están cabe la Trinidad frontero del Río, y combidar a algunos maestros de la Universidad con los quales piamente creo yo que gastó lo más del extraordinario que estaba para los colegiales esta Pascua ${ }^{68}$.

A pesar de que aparentemente los visitadores tenían estima y daban crédito a las palabras de Escribano, es bastante elocuente la falta de rigor contra el vicerrector e indicarían, por tanto, que sus aseveraciones no iban desencaminadas. Todo apunta a que Escribano sabía más de la cuenta, sobre todo al incriminar a otros profesores universitarios que, aunque no daba nombres, se congraciaban con Cristóbal del Río $\mathrm{y}$, en consecuencia, no hicieron mucho -sino más bien lo contrario- por expulsar a un vicerrector negligente.

A estas alturas, parece muy probable que Cristóbal del Río y algún miembro del Trilingüe cercano a él estuvieran detrás de las delaciones contra el bachiller ante la Inquisición. Aun así, creemos que fue necesaria la ayuda de alguien más que tuviera cierta familiaridad con el vicerrector y el Trilingüe y que, a su vez, estuviera lo suficientemente distante de los hechos para no ser tenido por contrario. La hipótesis que establecemos es que el proceso inquisitorial contra Juan Escribano estuvo ligado a una animadversión personal del vicerrector y su grupo que se materializó en acusaciones originadas en el seno del Trilingüe. Éstas se habrían disfrazado de falta doctrinal aprovechando lo sucedido con el tema de la confesión y la comunión de 1573 , lo cual concordaría con el requerimiento como testigo de la defensa de Escribano, según vimos en las cartas, de Francisco Gómez, cura de la Magdalena ${ }^{69}$. Posiblemente tendría que haber dado cuenta de si el helenista se confesaba y comulgaba en su parroquia como afirmaba, pero su muerte había dejado esta cuestión en el aire.

A pesar de que la duda sobre las prácticas doctrinales de Juan Escribano no conllevó en su día nada más que una reprimenda, sí que habría dejado el terreno abonado para que sus enemigos hubieran vertido alguna acusación más grave, esta vez proferida, quizás, por algún personaje con mayor influencia. En este contexto puede

\footnotetext{
67 El vicerrector Cristóbal del Río, que había sido encarcelado en septiembre de 1575 por descubrirse faltas de 170.000 maravedís, aun elevó una petición al claustro universitario para que fuera rehabilitado en su cargo, algo a lo que la Universidad no accedió. Véase LóPEz RuEDA, op. cit. (nota 9), p. 90

68 AUSA, Visitas Trilingüe, leg. 2134, s/fol.

69 Carta del Tribunal de Valladolid, fechada en 16 de noviembre de 1575 y recibida en Madrid el 21 de noviembre de 1575, AHN, Inquisición, Cartas, leg. 3192, exp. 186.
} 
entenderse tanto lo mencionado en las cartas sobre la Vulgata ${ }^{70}$ como las acciones en contra de su persona que tuvieron lugar tras su rehabilitación en la Universidad de Salamanca. Estas serían protagonizadas, precisamente, por algunos catedráticos del claustro, uno de ellos - ¿casualidad?- visitador del Trilingüe.

\subsection{Enemigos en el claustro universitario}

Juan Escribano, en la petición elevada al claustro cuando se reincorporó a la Universidad tras salir de la cárcel, solicitó, en primer lugar, que se le rehabilitase en su puesto en el Trilingüe sin tener que vivir en él, y, en segundo lugar, que se le diera algo con lo que salir adelante. En esos momentos es de suponer que, como vimos durante su estancia en prisión, estaría pasando por verdaderas dificultades económicas. La reinserción en las aulas universitarias se debatió y sometió a votación en el mismo claustro pleno, mientras que la ayuda se tramitaría en el claustro de diputados del 17 de noviembre.

Al leer ambas reuniones, todo parece en orden. En la primera de ellas se realizó un amplio alegato del trabajo y la gestión de Escribano en el Trilingüe -ninguna novedad-y se propuso su aprobación por parte del vicerrector Nuño de Villavicencio "atento que lo merece todo, así por sus buenas partes como por la gran falta que al presente hay de una persona que enseñe la lengua griega, en la cual es muy perito [...]"'71. La petición se sometió a votación pública, de modo que cuando había algún catedrático que se ausentaba solía delegar su voto en otro colega. Sin embargo, hubo tres ausencias que, a priori, deberían haber pasado desapercibidas, ya que tampoco era raro marcharse del claustro sin expresar el sentido de su voto. Los ausentes fueron el doctor Frechilla, y los maestros Enrique Hernández y fray Bartolomé de Medina $^{72}$. El resto del claustro presente aprobó por unanimidad la rehabilitación del bachiller Escribano.

Este detalle no habría tenido mayor importancia si fray Bartolomé de Medina no hubiera delatado con anterioridad a Fray Luis de León, hostilidad que podría haberse extendido hacia su círculo ${ }^{73}$. Sumado a ello, también fue el que había señalado a Cantalapiedra como "amigo de letras humanas", en un momento en el que el maestro de hebreo afirmó su amistad con Juan Escribano ${ }^{74}$. Quizás podrían haber concurrido otros motivos para haberse ausentado de la votación, aunque resulta algo sospechoso el mutismo con el que se marcharon sin expresar el sentido de su voto a ningún colega. Además, sabiendo que el aplauso del claustro al trabajo de Escribano era

\section{Ibidem.}

71 Beltrán de Heredia, op. cit. (nota 3), pp. 310-311. En esta ocasión consiguió que se aprobasen los 30.000 maravedís que cobraba de salario antes de entrar en prisión más otros 20.000 para que se sustentase fuera del Trilingüe, petición que ya hizo antes de que lo encarcelasen.

72 AUSA, Claustros, leg. 45, fol. $164 \mathrm{v}$.

73 Juan Escribano aparece como testigo en las defensas durante el proceso de Fray Luis de León en 1573, con el cual parece que mostraba ciertas simpatías. Véase SAlví y SAINZ de BARANDA, op. cit. (nota 5), pp. 306-308. También lo cree Eugenio Asensio, el cual relaciona a Escribano y a los seguidores de las obras de Pierre de la Ramée con el círculo aperturista de Fray Luis de León. Véase AsEnsio, E.: "El ramismo y la crítica textual en el círculo de Luis de León: carteo de El Brocense y Juan de Grial”, en García DE LA Concha, V. (coord.): Fray Luis de León [Actas de la I Academia Literaria Renacentista, Salamanca 10-12 de diciembre de 1979], Salamanca, 1993, pp. 64-66. Sobre todas estas relaciones, véase RuBio MuÑoz, op. cit. (nota 18).

74 Bartolomé de Medina había acusado a Cantalapiedra diciendo que se "sospecha que el dicho maestro Martínez [de Cantalapiedra], y ciertas otras personas que nonbró, llevaron otras personas de cierta qualidad que declaró consigo, [como] amigo de letras humanas". Véase De la PinTa Llorente, op. cit. (nota 5, 1956), p. 211. 
casi unánime y que la votación era pública, se podría pensar que cualquier opinión en contra de la decisión mayoritaria del claustro habría dejado en evidencia a quien la manifestase. Este hecho, en relación a alguien que había estado encarcelado por la Inquisición, habría resultado demasiado flagrante. En cualquier caso, no hemos encontrado indicios de enemistad entre el Doctor Frechilla y Juan Escribano, aunque sí que podrían existir por parte del otro catedrático que se ausentó de la votación, el maestro Enrique Hernández de Sande, catedrático de filosofía y visitador del Trilingüe, cuya posible animadversión contra Juan Escribano se desconocía hasta ahora.

La votación del 17 de noviembre de 1576 sobre la ayuda pedida por Juan Escribano para hacer frente a sus deudas parece que podría concordar con la hipótesis planteada. En el claustro de diputados de ese día estaban presentes tanto el maestro Enrique Hernández como fray Bartolomé de Medina; no así el Doctor Frechilla. No obstante, el maestro Medina entró a mitad de la sesión, aunque antes de la votación sobre la petición de Escribano, mientras que el maestro Hernández se ausentaba casi al final del claustro, poco antes de opinar acerca de la cuestión del bachiller. Enrique Hernández, en el momento de marcharse, delegó su voto en el licenciado Francisco Lobo, diputado, "para todo lo contenido en la dicha cédula", que, debido a lo avanzado del claustro, no restaba más que votar sobre unos pagos a los correos de la Universidad, y la cuestión de Juan Escribano ${ }^{75}$. En este último punto, se propuso darle al regente de griego una limosna de doce ducados. Realizadas las votaciones - esta vez en secreto- "parezieron tres agallos negros, por do constó aver sido contradicho, e así no se le dio ninguna cosa"76. Una vez más, y a pesar de las loas que se le habían hecho poco antes, Juan Escribano tendría que afrontar un nuevo revés.

Ahora bien, ¿sería aventurado pensar que Bartolomé de Medina y Enrique Hernández estaban detrás de los tres votos en contra? Realizando un simple ejercicio comparativo de los asistentes a ambos claustros podríamos hallar respuestas. Así, teniendo en cuenta que todos los asistentes al claustro pleno (a excepción de los que se marcharon sin delegar su voto) votaron afirmativamente a la reincorporación de Escribano, cabría esperar también una decisión favorable a la concesión de la ayuda al bachiller en el claustro del 17 de noviembre. Frente a ello, los ausentes en el claustro pleno que no declararon su intención coincidirían, en primer lugar, por descarte, pero también por otras razones, con los tres votos que negaron la ayuda a Juan Escribano. En este sentido, hay que recordar que tanto Medina como Hernández estuvieron ausentes en el claustro de la reincorporación de Escribano, cuyas deliberaciones eran públicas, y que se encontraban entre los que votaron o delegaron su voto secreto en la segunda petición. Además, la situación cuadraría sin problemas: el voto de Francisco Lobo tendría que ser negativo para que el de Enrique Hernández lo fuera, los cuales, sumados al de Medina, darían tres, que son las agallas negras que salieron ${ }^{77}$.

AUSA, Claustros, leg. 46, fol. $13 \mathrm{v}$.

76 AUSA, Claustros, leg. 46, fol. 13 v. Hemos de recordar que las agallas negras se utilizaban para votar secretamente en contra de la resolución, y las blancas para votar a favor de la misma. Como la decisión tendría que ser por unanimidad, los tres votos en contra supusieron la denegación de la petición de Escribano.

77 Los miembros del claustro favorables a la reincorporación de Escribano que estuvieran presentes en ambas sesiones fueron: los doctores Solís (cancelario), Martín de Busto, Miguel Dacosta, Pedro Fernández de Torquemada y Cosme de Medina; los maestros Francisco Sánchez de las Brozas y Francisco de Salinas; Fray García del Castillo, que delega su voto en el rector, el Licenciado don Antonio de Quesada (que era amigo de Cantalapiedra), Juan Ramírez del Arroyo, y Bautista Romero. Éstos, junto a los que no estuvieron presentes en el primer claustro, que eran el nuevo rector don Álvaro de Mendoza; el doctor Cristóbal Arias, síndico; Martín Sánchez Portocarrero y el Doctor Moya, se presupone que votarían a favor. Frente a ellos, coinciden los nombres de los que se ausentaron en el claustro pleno sin mostrar su opinión con los que podrían haber votado 
Posiblemente estemos ante dos enemigos del helenista desconocidos hasta ahora, dado que, siendo difícil para ellos oponerse públicamente a la vuelta a las aulas del bachiller de griego, podrían haber boicoteado, de una forma subrepticia, la tan necesaria ayuda para comenzar a remediar su situación ${ }^{78}$. Ya mencionamos los indicios que podrían ligar a Fray Bartolomé de Medina con el caso de Escribano, y que tendrían como posible móvil su enemistad con Fray Luis y Cantalapiedra, a cuyo círculo pertenecería el regente de griego. Los de Enrique Hernández, empero, no quedan claros a menos que echamos un ojo, de nuevo, al proceso contra Cantalapiedra.

A lo largo del interrogatorio en el proceso contra el maestro Martínez de Cantalapiedra mencionamos que se infería cierta relación cercana de éste con Juan Escribano ${ }^{79}$. Pero en el proceso contra el primero también aparecía el maestro Enrique Hernández, el cual realizó una declaración muy llamativa en relación al bachiller Escribano. Hernández es llamado como testigo en defensa de Cantalapiedra, el 15 de noviembre de 1575, cosa para la que también había sido propuesto Escribano con anterioridad, aunque no sabemos si este último llegó a declarar ${ }^{80}$. Preguntado por si sabía las razones por las que estaba llamado por el Santo Oficio, "dixo que no sabe para qué es llamado, demás de que sospecha si es llamado para alguna cosa de Juan Hescribano, preso en la cárcel del Santo Oficio, por aber éste que depone sido besitador del Colegio Trilingue, donde él residía"81. Es curioso, cuanto menos sospechoso, que el maestro Hernández expresase que estaba en el Santo Oficio para hablar de "alguna cosa de Juan Hescribano", cuando nadie le había nombrado previamente al bachiller. Parece que él, en tanto que era visitador del Trilingüe, asumió un papel, acaso de delator o de testigo, en el proceso contra el helenista. ¿Excusatio non petita, acusatio manifiesta?

\subsection{Intentos de clausura del Trilingüe}

Por si fuera poco, hay un último elemento relacionado con el maestro Hernández que podría añadirse a las sospechas que tenemos sobre su relación con el caso del bachiller Juan Escribano, que no es otro que la pretensión de cerrar el Colegio Trilingüe. Los libros de claustro indican que Hernández no era precisamente favorable a mantenerlo abierto. En el claustro del 20 de noviembre de 1571, ante los problemas de disciplina habidos en el Trilingüe, el maestro Hernández de Sande votó "que el dicho Colegio Trilingüe se quite y no le aya por el poco fruto que en él se ha hecho" ${ }^{" 22}$. En

en contra de la concesión de limosna a Escribano, si descartamos al Dr. Frechilla que no estuvo presente en el último claustro: Fray Bartolomé de Medina, el maestro Enrique Hernández, y la persona en quien delegó su voto, el Licenciado Francisco Lobo, que curiosamente sí estuvo a favor de la reincorporación de Escribano en el claustro pleno anterior y habría cambiado su decisión en función del criterio de Hernández. AUSA, Claustros, leg. 45, fols. 162 r - 164 v y AUSA, Claustros, leg. 46, fols. 9 r - 12 r.

78 López Rueda baraja esta posibilidad a raíz de la salida del claustro de estos tres catedráticos, y la votación en contra de tres de los presentes en el posterior claustro de diputados del 17 de noviembre de 1576. Sin embargo, no establece ninguna relación sobre las causas, más allá de que Bartolomé de Medina había delatado a Fray Luis de León. Véase LóPEZ RuEDA, op. cit. (nota 9), p. 101.

79 Véase nota 32.

80 El maestro Enrique Hernández, a pesar de que había sido convocado para la defensa de Cantalapiedra ante la supuesta inquina que el maestro Gallo tenía contra el preso, dijo "que no sabe que [Gallo] aya jurado ni depuesto en esta causa, ni que aya sido enemigo del dicho maestro Martínez". Por tanto, no le fue de gran ayuda. Véase De la Pinta Llorente, op. cit. (nota 5, 1956), p. 289.

81 Ibidem.

82 AUSA, Claustros, leg. 41, fols. 9r-10v. Manifestaba ser de la opinión del doctor Francisco de Castro, el cual dijo que "su voto hera y es que el dicho Colegio se quite y no lo aya porque los colegiales que en él viven andan muy 
ello coincidía con los doctores Francisco de Castro, síndico, y Martín de Busto, si bien el primero se retractó al final del claustro, prefiriendo que se visitase nuevamente para encontrar una solución.

No fue la única ocasión en la que el maestro de filosofía sostuvo en público su interés por clausurar el Colegio donde enseñaba Juan Escribano. Precisamente, pocos días después de que Juan Escribano entrase en prisión, el 25 de enero de 1575 el rector don Juan de Acuña somete a votación la venta del Trilingüe. Con uno de los mejores valedores de la enseñanza de griego entre rejas, se abordaba la venta del edificio aun inconcluso, "atento que ay persona que lo pagará muy bien, pues de presente la Universidad está tan necesitada y según su necesidad se dize no se poder acabar en muchos años y con muy grande costa"83. Sin embargo, el claustro rechazó finalmente la propuesta de venta.

Tres días después, en claustro pleno, la comisión encargada de dar solución al Trilingüe propone su cierre temporal para que "el gasto que se hace en el Colegio Trilingüe con los regentes y colegiales y con las demás personas de dicho Colegio cesase, para que con el gasto [...] se podrá acabar con brebedad la obra del dicho Colegio" 84 . Hemos de decir que el maestro Hernández no estuvo presente en el claustro donde se trató la venta del edificio, aunque sí lo estaba ahora, y su opinión, como se puede intuir, no fue proclive a mantenerlo abierto, al igual que la de Fray Bartolomé de Medina y Frechilla, entre otros. Frente a ellos, León de Castro, El Brocense y algunos más se opusieron a la clausura. El resultado de la votación fue de veinte votos a favor de la continuidad del Colegio frente a dieciséis favorables al cierre. Por esta vez, el Trilingüe se salvaba.

Llegados a este punto, cabría lanzar una hipótesis: ¿había sido aprovechado el momento en el que Escribano estaba en prisión para intentar terminar con el Trilingüe? Es complicado ofrecer una respuesta cerrada. Por un lado, es cierto que el funcionamiento del Colegio no era el apropiado, y había más catedráticos que en algún momento sopesaron cerrarlo. Pero también es verdad que, si el vicerrector Cristóbal del Río tenía buenas relaciones con algunos miembros del claustro universitario, no habría razones para pensar que éste y su círculo -al que podría haber pertenecido el maestro Hernández-deseasen el cierre del Trilingüe.

\section{Conclusión}

Los hechos descritos hasta aquí tienen varios componentes en común: el bachiller Juan Escribano, el vicerrector Cristóbal del Río, el maestro Enrique Hernández, fray Bartolomé de Medina y el Colegio Trilingüe. Todos parecen confluir en el proceso contra el regente de griego, $\mathrm{y}$, sin que parezca precipitado, podríamos decir que entre todos o algunos de ellos se articuló una trama para denunciar al helenista ante el San-

destraydos y es gente sin provecho y tanto que desde que se hizo y fundó el dicho Colegio, ha diecisiete años poco más o menos, la Universidad ha gastado más de 15.000 ducados e probecho no se ha sentido ninguno, e que pide e requiere a los dichos señor rector y maestrescuela y a toda la congregaçión le manden quitar [...]". Véase Carabias TORRes, op. cit. (nota 14), p. 154.

83 AUSA, Claustros, leg. 44, fols. 44 r-46 r. El doctor Antonio de Solís, vicescolástico y contrario a la venta, recordó que el tema ya se había tratado durante el rectorado de don Diego de Castilla, momento en el que el arzobispo de Sevilla quiso comprarlo, y el claustro resolvió no venderlo. Véase SÁNCHEZ y SÁNCHEZ, op. cit., (nota 20), p. 473.

84 AUSA, Claustros, leg. 41, fols. 47v-49v. Véase LóPEz RUEDA, op. cit. (nota 9), p. 90. 
to Oficio. No conocemos con seguridad el móvil de la posible delación más allá de la animadversión entre Cristóbal del Río y Juan Escribano, aunque quizás el vicerrector perteneciera al círculo del maestro Hernández o Fray Bartolomé de Medina, y éstos pudieran haberse visto perjudicados por la declaración de Escribano acusando a del Río de connivencia con otros catedráticos. Lo que sí parece claro es que las acusaciones del vicerrector y su camarilla tuvieron la intención de incriminar a Escribano alguna falta doctrinal, sabiendo que podría conllevar la prisión del helenista, y éste era consciente de ello. Relacionarlo con el cuestionamiento de la Vulgata era algo aparentemente sencillo: tal era la causa por la que Fray Luis, Cantalapiedra y Grajal estaban en prisión, $\mathrm{y}$, dado que parecía que tenía relación con alguno de ellos, no habría sido complicado hacerle partícipe de su pensamiento. No debemos olvidar que Escribano, al igual que sus colegas, eran profundos conocedores de las lenguas antiguas, lo cual era un aliciente más para estar en el punto de mira de las denuncias inquisitoriales por realizar una exégesis bíblica que no fuera la ortodoxa.

Oficialmente, esta cuestión teológica sobre la Vulgata habría sido el detonante de su proceso, pero todo apunta a que las verdaderas causas radicaron en venganzas personales, al igual que ocurrió con el proceso de los hebraístas. Juan Escribano se había convertido en un inquilino incómodo del Colegio, que sabía, quizás, demasiado. Su mayor error habría sido no sólo denunciar las irregularidades del Colegio y de su vicerrector -acciones aplaudidas cínicamente por visitadores y claustro- sino, además, señalar la familiaridad de éste con otros catedráticos. Aun sin dar nombres, Escribano posiblemente cometió la torpeza de quejarse de ello a las personas equivocadas, que tal vez -y aquí entraría el maestro Hernández o Bartolomé de Medinaeran las mismas que habían compartido algunos de los convites del vicerrector. Así pues, no sería desacertado pensar que, debido a ello, algunas acciones del maestro Enrique Hernández fueron encaminadas a perjudicar al bachiller Escribano, el cual se había llevado el aplauso de sus colegas en varias ocasiones. Hernández, como visitador del incómodo Trilingüe, quizás habría tenido como objetivo facilitar su cierre debido a su mal funcionamiento. A pesar de que en la sucesión de hechos descritos parece que había algo más que casualidades, no podemos aseverarlo con total seguridad por la ausencia del documento del proceso inquisitorial.

En suma, el proceso inquisitorial contra el bachiller Juan Escribano debe ser contextualizado dentro de la atmósfera intolerante que envolvió a la segunda mitad del siglo XVI, en donde la Inquisición persiguió a todo aquel que mostrase, en público o en privado, comportamientos o pensamientos heterodoxos. Debido a ello, las cuestiones teológicas se mezclaban con las personales, de forma que la delación ante el Santo Oficio fue un hecho que escondía, en muchas ocasiones, enemistades y venganzas que poco tenían que ver con el cuestionamiento de la doctrina. El caso del regente de griego fue uno más a los que añadir a la larga lista de intelectuales procesados por la Inquisición, del mismo modo que había ocurrido con sus colegas hebraístas. La Universidad de Salamanca, entre tanto, callaba con aquiescencia mientras algunos de sus arduos defensores sufrieron el rigor inquisitorial, causado, como hemos visto, por la animadversión de otros colegas o de quienes, paradójicamente, la perjudicaban. 